\title{
The Kent-Rosanoff word association: word association norms as a function of age
}

\author{
M. E. Tresselt and M. S. Mayzner \\ NEW YORK UNIVERSITY
}

\begin{abstract}
If communality of responses is stable, the relative popularity of responses to the Kent-Rosanoff Word Association Test should remain the same for subjects from young adulthood to advanced age. The KentRosanoff was administered individually to 738 subjects from 18 to 87 years of age from various occupations and from various parts of the country. The results indicate that there is a decrease in the strength of communality accompanied by an increase in variability with the advance in age.
\end{abstract}

\section{Problem}

Because of the interest in verbal processes, word association lists are being used as stimulus-materials more and more frequently. The original study by KentRosanoff (1910) has been the most cited normative material in the past. But since the description of the characteristics of the group constituting their adult subjects is not made clear, the more recently collected normative data provided by Russell and Jenkins (1954) on Minnesota University students has been used often. As long as student groups are used for experimentation, there are no better norms than those of Russell and Jenkins, but if an older age group is used, the question may be asked whether the communalities remain the same.

\section{Subjects}

In order to examine the responses and at the greatest age difference available, 738 subjects were tested from the ages of 18 to 87 years. These individuals represented as much of a cross section of the population as possible, ranging from unskilled laborers to professional persons, and from different parts of the country. All individuals were non-hospitalized (except for three tubercular cases in a sanitarium in the old age group).

\section{Procedure}

Each S, individually, was given the Kent-Rosanoff orally and their responses recorded. The actual testing situation varied since Ss were obtained in the normal course of their day, i. e., laborers on a railroad track; travelers on a plane, etc. The S was only asked for his birthdate and occupation as identification.

\section{Results and Diseussion}

When the most frequent responses of two contrasted groups, 18-21 year group $(\mathrm{N}=105)$ and the 55-87 year group $(\mathrm{N}=105)$, were compared, $72 \%$ of the popular responses remained essentially the same, while $28 \%$ showed a shift. Thus, the stimulus-word "eating" had a popular response of "food" in the 18-21 year group while the popular response was "drinking" in the 55-87 year group. The suggestion might be made that the changed popular responses became more related to a problem area associated with the old-age group, e. g., the stimulus word "eating", produced "drinking", which could be an activity denied to the older age group; "beautiful", as a stimulus word evoked "ugly" instead of "pretty,", again a reflection of the changes brought about

Table 1. Percentage of Subjects Responding to 100 Common Word Associates for Group A (ages 18-33 years, N=373), Group B (ages 34-49, N = 205) and Group C (ages $50-87, \mathrm{~N}=160$ )

A Sample of the First 24 Words

$\begin{array}{lccc}\begin{array}{l}\text { Common Word } \\ \multicolumn{1}{c}{\text { Associates }}\end{array} & \text { A } & \text { B } & \text { C } \\ \text { table-chair } & 91 & 69 & 43 \\ \text { dark-light } & 84 & 78 & 59 \\ \text { music-song } & 16 & 13 & 14 \\ \text { sickness-health } & 50 & 43 & 26 \\ \text { man-woman } & 84 & 70 & 60 \\ \text { deep-shallow } & 33 & 32 & 36 \\ \text { soft-hard } & 52 & 60 & 56 \\ \text { eating-food } & 14 & 21 & 16 \\ \text { mountain-hill } & 36 & 31 & 22 \\ \text { house-home } & 16 & 13 & 13 \\ \text { black-white } & 80 & 64 & 61 \\ \text { mutton-lamb } & 40 & 36 & 29\end{array}$

$\begin{array}{lrrr}\begin{array}{l}\text { Common Word } \\ \multicolumn{1}{c}{\text { Associates }}\end{array} & \text { A } & \text { B } & \text { C } \\ & & & \\ \text { comfort-ease } & 15 & 21 & 23 \\ \text { hand-foot } & 35 & 33 & 39 \\ \text { short-tall } & 55 & 49 & 24 \\ \text { fruit-apple(s) } & 39 & 28 & 37 \\ \text { butterfly-insect } & 12 & 17 & 11 \\ \text { smooth-rough } & 33 & 38 & 47 \\ \text { command-order } & 34 & 37 & 26 \\ \text { chair-table } & 68 & 46 & 20 \\ \text { sweet-sour } & 51 & 50 & 44 \\ \text { whistle-blow } & 10 & 9 & 16 \\ \text { woman-man } & 71 & 58 & 51 \\ \text { cold-hot } & 55 & 47 & 43\end{array}$


in old age; "sleep" evoked "awake" instead of "bed" or "dream" as in the younger age group, when lying awake at night is a common complaint in the older ages; "doctor" brought the response "medicine" most popularly in the old age rather than "lawyer" in the younger group.

The comparison of the two age groups is marked by a significant change $(\mathrm{P}<.001$ using the sign test) in the variability of responses; for example, the word "table" in the 18-21 year group produced 13 different responses, whereas 36 different responses were produced by the older age group. The increase in variability might be due to the development of rugged individualism in the older age group as contrasted with a drive to conform in the younger group.

Although the larger percentage of most common responses remained the same, the significant increase in variability necessarily means that the absolute number responding with a common associate must decrease. Therefore, an analysis was made on the most common response in a newly constructed combination group ages 18-33 ( $\mathrm{N}=373)$ and compared to a group of ages 34-49 $(\mathrm{N}=205)$ and $50-87$ years $(\mathrm{N}=160)$. The groupings were arbitrarily delineated from the separate norms of Tresselt et al., (1953a, 1953b, 1954, 1955, $1959,1960)$. A sampling of the results for the first 24 words are presented in Table 1. An analysis was carried out on the total 100 words using the Friedman 2 -way analysis of variance and the results indicated a significant decrease in the popularity of the most common responses from the younger age group to the older age group $\left(\chi_{r}^{2}=87.98 ; P=.001\right.$ when $\left.\chi_{r}^{2}=13.82\right)$.

\section{References}

KENT, G. H., \& ROSANOFF, A. J. A study of association in insanity. Amer. J. Insanity, 1910, 67, 37-96, 317-390.
RUSSELL, W. A., \& JENKINS, J. J. The complete Minnesota norms for responses to 100 words from the Kent-Rosanoff word associates test. USN Tech. Rep. No. 11, 1954, ONR N8 onr 66216, Univ. Minnesota, 1854.

TRESSELT, M. E. The responses and frequencies of responses for 108 subjects (ages 34-41) to the KentRosanoff word list. Psychol. Newsl., 1959, 10, 176-212.

TRESSELT, M. E. The responses and frequencies of responses for 122 subjects (ages 42-54) to the KentRosanoff word list. J. Psychol. Studies, 1960, 11, 118-146.

TRESSELT, M. E., \& LEEDS, D. S. The responses and frequencies of responses for males and females (ages 18-21) to the Kent-Rosanoff List. Psychol. Newsl., 1953a, 5, 1-36.

TRESSELT, M. E., \& LEEDS, D. S. The frequencies of responses by males and females $(\mathrm{N}=124)$ for each of the 100 Kent-Rosanoff stimulus words (ages 22-25). Psychol. Newsl., 1953b, 5, 39-74.

TRESSELT, M. E., \& LEEDS, D. S. The responses and frequencies of responses for males and females (ages 26-29) to the Kent-Rosanoff word list. Psychol. Newsl., 1954, 5, 144-177.

TRESSELT, M. E., \& LEEDS, D. S. The responses and frequencies of responses for males and females (ages 30-33) to the Kent-Rosanoff word list. Psychol. Newsl., 1955, 6, 95-127.

\section{Note}

1. This study was supported in part by a grant made to M. E. Tresselt by the New York University Arts and Sciences Research Fund. The authors wish to express their appreciation for data collected by Dr. Carl Eisdorfer, Mr. Donald Leeds, Dr. Bernard Levy among others, and to Miss Gail Amon for the tabulation of the norms. A detailed mimeographed copy of the responses and frequencies of responses for ages 55-87 can be obtained from the senior author upon request. 